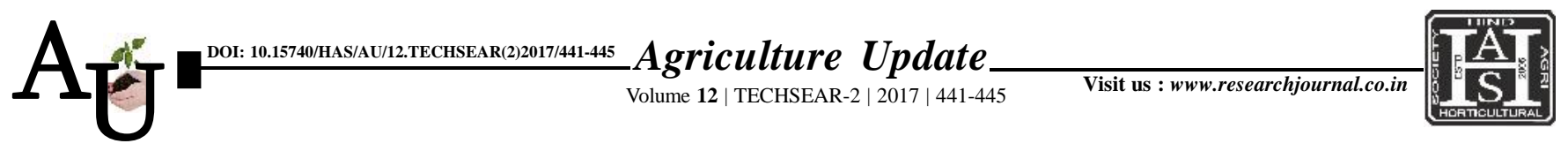

— e ISSN-0976-6847

\title{
Research article: Antimicrobial activities of important mushrooms against Alternaria solani
}

\section{K.P. PATIL, G.K. AWADHIYA AND C.R. GIRASE}

Article Chronicle: Received :

11.07.2017;

Accepted :

24.07.2017]

KeY Words:

Antimicrobial activities, Alternaria solani, Mushroom extracts, Poisoned food technique, Fruiting bodies

\section{Author for correspondence :}

\section{K.P. PATIL}

Department of Plant Pathology, Indira Gandhi KrishiVishwavidyalaya, RAIPUR (C.G.) INDIA

Email:patilkushavart37

@ gmail.com

See end of the article for authors' affiliations
SUMMARY : Antimicrobial study was carried out by poisoned food technique against the pathogens by using the methanol, acetone and water extracts. The methanol, acetone and water extracts of mushroom species namely G. lucidum, G. sapidum, P. florida, Russula sp., Boletus edulis and combination of Russula sp. with Curcuma caesia showed well per cent growth inhibition against Alternaria solani except in Agaricusbisporus which showed zero per cent growth inhibition in all 5 per cent, 10 per cent, 20 per cent and 40 per cent concentrations, respectively. G.lucidum, Boletus edulis and combination of Russula sp. with Curcuma caesia are the most promising species as antimicrobial agents.

How to cite this article : Patil, K.P., Awadhiya, G.K. and Girase, C.R. (2017). Antimicrobial activities of important mushrooms against Alternaria solani. Agric. Update, 12(TECHSEAR-2) : 441-445; DOI: 10.15740/ HAS/AU/12.TECHSEAR(2)2017/441-445. 